\title{
MEMBANGUN KESADARAN JAJANAN AMAN PADA ANAK SEKOLAH
}

\author{
BUILD AWARENESS OF SAFE SNACKS FOR ELEMENTARY SCHOOL CHILDREN
}

\author{
Zulfiayu Sapiun, Paulus Pangalo, Heny PanaI, Sukma Damiti \\ Program Studi D III Famasi Politeknik \\ Politeknik Kesehatan Gorontalo \\ zulfiayu@poltekkesgorontalo.ac.id
}

\begin{abstract}
Abstrak
Tujuan Kegiatan untuk mengetahui tingkat pengetahuan dan sikap siswa/siswi sebelum dan sesudah penyuluhan dilaksanakan dan memastikan bahwa jajanan di sekitar sekolah aman dari cemaran kimia. Kegiatan ini adalah quasi eksperiment. Alat ukur adalah kuesioner berisi pernyataan pengetahuan dan sikap. Pengetahuan dan sikap dinyatakan baik bila nilai $\geq 75$. Data dianalis dengan univariat dan perubahan diuji dengan wilcoxon. Kegiatan berupa penyuluhan keamanan pangan dan pengujian sampel makanan jajanan di sekitar sekolah. Pengetahuan siswa tentang jajanan aman adalah sebelum penyuluhan adalah 3,79 dan setelah sebesar 4,65. Sikap siswa tentang jajanan aman adalah sebelum penyuluhan adalah 4,90 dan setelah sebesar 5,75. Tingkat pengetahuan siswa MIN 1 Kota Gorontalo 35\% kurang baik dan 65\% baik. Sedangkan setelah kegiatan menjadi $10 \%$ kurang baik dan $95 \%$ baik. Sikap siswa MIN 1 Kota Gorontalo sebelum kegiatan adalah $37 \%$ kurang baik dan $63 \%$ baik, sedangkan setelah kegiatan $5 \%$ kurang baik dan $95 \%$ baik. Hasil pengujian Wilcoxon menunjukkan bahwa penyuluhan tentang jajanan aman telah mampu mengubah pengetahuan secara signifikan dengan nilai $\mathrm{P}=0,000$, dimana $\mathrm{P}<0,05$. Hasil pengujian Wilcoxon menunjukkan bahwa penyuluhan tentang jajanan aman telah mampu mengubah sikap secara signifikan dengan nilai $\mathrm{P}=0,000$. dimana $\mathrm{P}<0,05$. Hasil pengujian jajanan didapatkan 10 sampel uji negatif mengandung metanil yellow, rhodamin $\mathrm{B}$, borax, dan formalin.
\end{abstract}

Kata Kunci: Jajanan, Anak Sekolah, Cemaran Kimia, Keamanan

\begin{abstract}
This activity aims to determine the level of knowledge and attitudes of students before and after counseling is carried out and ensure that snacks around the school are safe from chemical contamination. This activity is a quasi experiment. The measuring instrument is a questionnaire containing a statement of knowledge and attitude. Knowledge and attitude are stated well if the value is $\geq 75$. Data was analyzed by univariate and changes were tested with Wilcoxon. Activities include counseling on food safety and testing samples of snacks around the school. Student knowledge about safe snacks was before counseling was 3.79 and after 4.65. The attitude of students about safe snacks is before counseling is 4.90 and after equal to 5.75. The level of knowledge of MIN 1 Gorontalo City students is 35\% less good and 65\% is good. Whereas after the activity it becomes $10 \%$ less good and 90\% good. The attitude of MIN 1 students in Gorontalo City before the activity was $37 \%$ less good and $63 \%$ good, while after the activity 5\% was not good and 95\% was good. The Wilcoxon test results showed that counseling about safe snacks was able to change knowledge significantly with a value of $P=0,000$, where $P<0.05$. The Wilcoxon test results showed that counseling about safe snacks was able to change attitudes significantly with a value of $P=0,000$. where $P<0.05$. The results of testing snacks obtained 10 negative test samples containing methanil yellow, rhodamine $B$, borax, and formalin.
\end{abstract}

Keywords: Snacks, Elementary School Children, Chemical Contamination, Food Security 


\section{Pendahuluan}

Segala sesuatu yang berasal dari sumber hayati produk pertanian, perkebunan, kehutanan, perikanan, peternakan, perairan, dan air, baik yang diolah maupun tidak diolah yang diperuntukkan sebagai makanan atau minuman bagi konsumsi manusia, termasuk bahan tambahan pangan, bahan baku pangan, dan bahan lainnya yang digunakan dalam proses penyiapan, pengolahan, dan/atau pembuatan makanan atau minuman merupakan definisi dari pangan berdasarkan Undang-Undang tentang pangan nomer 18 tahun 2012. Pangan yang dikonsumsi harus berkualitas dan dapat memenuhi kebutuhan manusia baik dari segi jumlah, jenis, maupun mutu, sehingga tidak akan menimbulkan penyakit bagi yang mengkonsumsinya. Pangan aman dikonsumsi apabila pangan tersebut bebas (di bawah toleransi maksimum yang dipersyaratkan) dari cemaran biologis, kimia, dan benda asing yang dapat mengganggu, merugikan, dan membahayakan manusia (Ningrum \& Wulan, 2017).

Varian jajanan pangan saat ini semakin hari semakin bertambah, salah satunya dikarenakan kreativitas dari penjaja semakin menigkat untuk menarik perhatian masyarakat yang memiliki daya konsumtif besar. Jajanan pangan dengan jenis beragam yang ditawarkan dengan harga murah dan dijajakan didalam ataupun sekitar sekolah memiliki daya tarik yang besar bagi anak sekolah. Pangan jajanan diharapkan selain harga yang murah dan jenisnya yang beragam, juga menyumbangkan kontribusi yang cukup penting akan kebutuhan gizi. Anak sekolah sangat menyukai pangan jajanan. Oleh karena itu, para pedagang berupaya untuk memberikan penampilan yang menarik dan rasa yang disenangi anak-anak dengan menambahkan bahanbahan tertentu tanpa memperdulikan keamanannya (Pakhri, A. et al, 2014).

Pangan jajanan dapat menimbulkan berbagai efek yang negatif terhadap kesehatan apabila proses produksinya atau penyajiannya tidak memperhatikan persyaratan keamanan pangan. Sebagian besar pangan jajanan dibuat di lingkungan keluarga sebagai industri rumah tangga, dimana perhatian terhadap praktek sanitasi dan higienitas masih sangat minimal khususnya dalam menangani, mengolah dan menyajikan pangan jajanan (Ningrum \& Wulan, 2017).

Menurut Rahayu (2014), kasus keracunan pangan yang paling sering dilaporkan dari tahun 2004-2014 di Indonesia adalah keracunan akibat pangan jajanan dan keracunan akibat pangan olahan. Pengujian yang dilakukan Badan Pengawasan Obat dan Makanan (BPOM) tahun 2014 terhadap pangan jajanan diketahui bahwa pada 13.536 sampel menunjukkan $11.871 \quad(87,69 \%)$ sampel memenuhi syarat dan $1.665 \quad(12,31 \%)$ sampel tidak memenuhi syarat. Pangan yang tidak memenuhi syarat disebabkan karena menggunakan pemanis buatan bukan untuk makanan diet (31\%), menggunakan benzoat melebihi batas (7,93\%), menggunakan formalin $(8,88 \%)$, menggunakan boraks $(8,05 \%)$, menggunakan pewarna bukan untuk makanan $(12,67 \%)$, cemaran mikroba $(19,10 \%)$ dan TMS lainnya (12,13\%) (Badan POM, 2009).

Masalah keamanan jajanan di sekitar sekolah antara lain ditemukannya (1) produk pangan olahan yang tercemar bahan berbahaya (mikrobiologis \& kimia), (2) pangan siap saji yang belum memenuhi syarat higiene \& sanitasi, dan sumbangan pangan yang tidak memenuhi persyaratan kesehatan. Penyebabnya, tata cara penanganan pangan yang mengabaikan aspek keamanan pangan, ketidaktahuan konsumen (anak-anak sekolah \& guru) akan pangan jajanan yang aman (Pakhri dkk, 2014).

Bahan Berbahaya terbagi atas 3 Jenis yaitu: Fisik (tanah, karet, plastik, rambut), Kimia (Boraks, Pewarna tekstil, formalin, bahan tambahan makanan), dan Biologis (Bakteri akibat kesalahan proses produksi, binatang) (Astariawati, 2016).

Anak sekolah sebagai konsumen utama PJAS adalah aset bangsa indonesia yang akan menjadi penerus kita di masa mendatang. Edukasi keamanan pangan menjadi salah satu upaya sehingga masyarakat memahami dan menerapkan perilaku keamanan pangan secara konsisten. 
Salah satu sarana edukasi tersebut adalah dengan kampanye "5 Kunci Keamanan Pangan untuk Anak Sekolah" yang berisi tips, pengetahuan dan prinsip mengenai praktek keamanan yang perlu dilaksanakan oleh anak sekolah dengan bahasa yang dipahami oleh mereka. Terdapt 5 kunci keamanan pangan untuk anak seklah, yaitu Kunci 1 : Kenali Pangan yang Aman, Kunci 2: Beli Pangan yang Aman, Kunci 3: Baca Label dengan Seksama, Kunci 4: Jaga Kebersihan, dan Kunci 5: Catat Apa yang Ditemui (Kemenkes , 2014).

Berdasarkan hal tersebut di atas maka dosen sebagai isisiator pengabdian kepada masyarakat berusaha mengetahui perubahan pengetahuan dan sikap anak Madrasah Ibtidaiyah Negeri terhadap keamanan pangan dan memastikan bahwa jajanan yang beredar di sekolah dimaksud tidak mengandung Bahan Tambahan Pangan (BTP) yang berbahaya bagi kesehatan. Adapun tujuan dari kegiatan ini adalah untuk mengetahui tingkat pengetahuan dan sikap siswa MIN 1 Kota Gorontalo sebelum dan sesudah pemberian materi keamanan pangan dan memastikan jajanan anak sekolah di lingkungan MIN 1 Kota Gorontalo aman dari BTP yang berbahaya bagi kesehatan

\section{Metode Penelitian}

Pelatihan cara mengetahui jajanan pangan yang aman bagi anak sekolah di MIN 1 Kota Gorontalo Provinsi Gorontalo memiliki rangkaian kegiatan sebagai berikut: persiapan berkoordinasi dengan pihak MIN 1 Kota Gorontalo untuk teknis tempat, waktu dan teknis kegiatan. Pelaksanaan, Memberikan materi kemanan pangan dari segi pemeriksaan fisik, Memberikan materi keamanaan pangan dari segi pemeriksaan kualitatif, Pengambilan sampel makanan, Pengujian sampel makanan

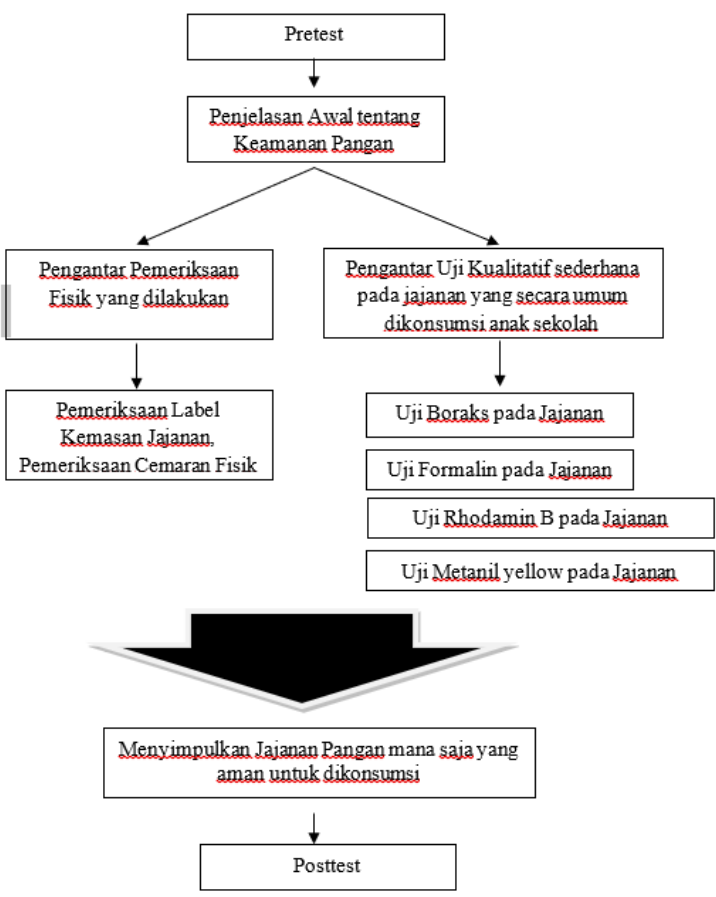

Gambar 1. Jalannya kegiatan

Beberapa institusi terkait:

1. Balai Pengawas Obat dan Makanan di Gorontalo

Keamanan pangan merupakan salah satu tugas pokok dan fungsi dari BPOM sehingga kegaitan ini meliabtkan BPOM sebagai salah satu narasumber dalam kegiatan ini dan menjadi pihak yang melakukan pengujian keamanan pangan.

2. Kementerian Agama

Membangun kesadaran kemanan Pangan Jajanan pada Anak Sekolah sangat penting, jika kesadaran akan bahaya dan manfaat yang dikonsumsi dipahami oleh seluruh anak sekolah sebagai generasi muda penerus bangsa maka program ini akan meningkatkan program pemerintah yaitu gerakan hidup sehat untuk meningkatkan gizi dari anak sekolah tersebut.

3. Madrasah Ibtidaiyah Negeri Negeri 1 Kota Gorontalo

Siswa-siswi MIN 1 dapat memelihara kesehatannya secara mandiri dengan membangun kesadaran jajanan yang aman untuk dapat dikonsumsi

4. Mahasiswa Prodi Farmasi Poltekkes Kemenkes Gorontalo

Kegiatan ini juga melibatkan mahasiswa sebagai pihak yang membantu pelaksanaan acara penyuluhan, 
pemberian pre dan post-test, pengambilan sampel makanan, dan pengujian bahan berbahaya.

Kegiatan ini adalah quasi eksperiment. Alat ukur adalah kuesioner berisi pernyataan pengetahuan dan sikap. Pengetahuan dan sikap dinyatakan baik bila nilai $\geq 75$. Data dianalis dengan univariat dan perubahan diuji dengan wilcoxon

Kegiatan Pengabdian kepada Masyarakat ini dilakukan pada hari Senin, tanggal 12 November di MIN 1 Kota Gorontalo melibatkan BPOM sebagai salah satu narasumber. Kegiatan ini diikuti oleh 100 (seratus) orang anak sekolah dari kelas 1 sampai kelas 6 dan didampingi oleh 37 orang guru. Sasaran kegiatan adalah murid MIN 1 Kota Gorontalo dari kelas 1 sampai kelas 6.

\section{Hasil}

\section{Karakteristik Responden}

Berdasarkan kegiatan yang dilaksanakan maka didapatkan karakteristik peserta sebagai berikut:

Tabel 1. Siswa-Siswi MIN 1 Kota

Gorontalo yang mengikuti kegiatan Pengabdian kepada Masyarakat Jajanan

\begin{tabular}{lllrr}
\multicolumn{5}{c}{ Aman } \\
\hline No & Karakteristik & Rincian & Jumlah & Persentase \\
\hline A & Jenis & Laki-laki & 37 & 37 \\
& Kelamin & & & \\
& & & & \\
\cline { 3 - 5 } & & Perempuan & 63 & 63 \\
\hline \multirow{2}{*}{ Kelas } & I & 22 & 22 \\
\cline { 3 - 5 } & & II & 14 & 14 \\
\cline { 3 - 5 } & & III & 9 & 9 \\
\cline { 3 - 5 } & IV & 18 & 18 \\
\cline { 3 - 5 } & V & 19 & 19 \\
\cline { 2 - 4 } & VI & 100 & 100 \\
\hline Total & &
\end{tabular}

\section{Pengetahuan Siswa terhadap Jajanan Aman}

Hasil uji pengetahuan siswa sebelum dan setelah kegiatan sebagai berikut:

Tabel 2. Pengetahuan Siswa MIN No 1 Kota Gorontalo terhadap Jajanan Aman

\begin{tabular}{llcc}
\hline No & \multicolumn{1}{c}{ Pernyataan } & Pre test & Post Test \\
\hline 1 & $\begin{array}{l}\text { PJAS } \\
\text { Jajanan Anak Sekolah }\end{array}$ & 1,0 & 1,0 \\
\hline 2 & $\begin{array}{l}\text { Cek KLIK berarti Cek } \\
\text { Kemasan, Label, Izin Edar, dan } \\
\text { Kadaluarsa }\end{array}$ & 1,0 & 1,0 \\
& $\begin{array}{l}\text { Rhodamin B termasuk pewarna } \\
\text { pangan yang aman }\end{array}$ & 0,7 & 0,8 \\
\hline 3
\end{tabular}

\begin{tabular}{llll}
\hline 4 & $\begin{array}{l}\text { Formalin merupakan pengawet } \\
\text { yang berbahaya bagi kesehatan }\end{array}$ & 0,7 & 1,0 \\
\hline 5 & $\begin{array}{l}\text { Pemanis buatan dapat memicu } \\
\text { penyakit kanker }\end{array}$ & 0,5 & 0,8 \\
\hline Total & & 3,79 & 4,55 \\
\hline
\end{tabular}

Pengetahuan siswa terhadap jajanan aman diuji dengan 5 (lima) pernyataan. Pada pernyataan pertama 1,0 mengetahui kepanjangan dari PJAS, yaitu Pangan Jajanan Anak Sekolah. Namun setelah kegiatan, 1,0. Kepanjangan dari Cek KLIK menunjukkan bahwa 1,0 benar dan meningkat menjadi 1,0 . Pertanyaan mengenai pewarna yang merupakan pertanyaan negativ menunjukkan bahwa 0,7 memiliki pengetahuan yang benar sebelum kegiatan dan meningkat menjadi 0,8 setelah kegiatan.

Pengenalan terhadap pengawet, salah satunya formalin yang telah banyak penggunaannya. Didapatkan sebelum kegiatn 0,7 mengetahui formalin termasuk pengawet yang berbahaya dan menjadi 1,0 setelah kegiatan. Pernyataan kelima yang menyatakan bahwa pemanis buatan dapat memicu kanker, didapatkan bahwa sebelum kegiatan 0,5 mengetahui hal tersebut sedangkan setelah kegiatan menjadi 0,8 . Hal ini menunjukkan bahwa pelatihan yang dilakukan telah mampu meningkatkan pengetahuan dari siswa sebanyak 0,76 , yaitu dari 3,79 menjadi 4,6.

Tabel 3. Tingkat Pengetahuan Siswa terhadap Jajanan Aman Sebelum dan Sesudah Kegiatan

\begin{tabular}{lcc}
\hline $\begin{array}{l}\text { Tingkat } \\
\text { Pengetahuan }\end{array}$ & $\begin{array}{c}\text { Sebelum } \\
\text { kegiatan }\end{array}$ & $\begin{array}{l}\text { Setelah } \\
\text { kegiatan }\end{array}$ \\
\hline Kurang baik & 35 & 10 \\
\hline Baik & 65 & 90 \\
\hline Total & 100 & 100 \\
\hline
\end{tabular}

Berdasarkan nilai dari masing-masing siswa, maka didapatkan bahwa tingkat pengetahuan siswa sebelum kegiatan sebanyak 35\% yang kurang baik dan $65 \%$ yang tergolong baik. Sedangkan setelah kegiatan, terdapat $10 \%$ yang memiliki tingkat pengetahuan yang kurang baik dan 90\% yang baik. Hal ini menunjukkan 
kegiatan yang dilakukan memberi dampak yang baik bagi pergeseran tingkat pengetahuan dari kurang baik menjadi baik.

Untuk menguji perubahan pengetahuan, maka dilakukan uji Wilcoxon karend didaptkan data itdak terdistribusi secara normal. Hasil uji adalah sebagai berikut:

Tabel 4. Hasil Uji Wilcoxon Pengetahuan Sebelum dan Setelah Intervensi

\begin{tabular}{lllll}
\hline Variabel & Rata-rata & Min & Max & Nilai P \\
\cline { 1 - 4 } $\begin{array}{l}\text { Pengetahuan } \\
\text { Sebelum Intervensi }\end{array}$ & $3,79 \pm 1,066$ & 1 & 5 & 0,000 \\
\cline { 1 - 3 } $\begin{array}{l}\text { Pengetahuan } \\
\text { Sesudah Intervensi }\end{array}$ & $4,55 \pm 0,716$ & 2 & 5 & \\
\hline
\end{tabular}

Berdasarkan hasil uji didapatkan nilai $\mathrm{P}=0,000$, dimana $\mathrm{P}<0,05$, sehingga dapat disimpulkan bahwa terjadi perubahan yang signifikan pada pengetahuan sebelum dan setelah perlakuan. Ini menunjukkan penyuluhan yang dilakukan efektif dalam melakukan perubahan pengetahuan.

\section{Sikap Siswa terhadap Jajanan Aman}

Hasil uji sikap siswa terhadap jajanan aman dapat dilihat pada tabel berikut:

Tabel 5. Sikap Siswa MIN No 1 Kota Gorontalo terhadap Jajanan Aman

\begin{tabular}{|c|c|c|c|}
\hline No & Pernyataan & Pre test & Post test \\
\hline 1 & $\begin{array}{l}\text { Anak Sekolah sebaiknya } \\
\text { sarapan terlebih dahulu di } \\
\text { rumah }\end{array}$ & 1,0 & 1,0 \\
\hline 2 & $\begin{array}{l}\text { Minuman yang berwarna } \\
\text { dan beraroma tidak } \\
\text { membawa akibat buruk } \\
\text { bagi kesehatan }\end{array}$ & 0,7 & 0,9 \\
\hline 3 & $\begin{array}{l}\text { Makanan dan minuman } \\
\text { yang sudah kadaluarsa } \\
\text { masih aman dikonsumsi }\end{array}$ & 0,8 & 1,0 \\
\hline 4 & $\begin{array}{l}\text { Kita harus mencuci } \\
\text { tangan terlebih dahulu } \\
\text { sebelum makan dan } \\
\text { minum }\end{array}$ & 0,9 & 1,0 \\
\hline 5 & $\begin{array}{l}\text { Membawa bekal dari } \\
\text { rumah tidak baik }\end{array}$ & 0,8 & 0,9 \\
\hline 6 & $\begin{array}{l}\text { Konsumsi fast food } \\
\text { hendaknya dibatasi }\end{array}$ & 0,8 & 1,0 \\
\hline Total & & 4,90 & 5,75 \\
\hline
\end{tabular}

Berdasarkan tabel 5, maka didapatkan sebelum kegiatan, 1,0 siswa menyatakan sikap bahwa anak sekolah sebaiknya sarapan terlebih dahulu di rumah sebelum dan setelah kegiatan. Pernyataan sikap ini dibutuhkan karena sarapan sangatlah penting untuk mengisi energi sebelum melakukan kegiatan belajar mengajar. Bagi anak yang tidak terbiasa makan pagi, jajanan di sekolah berfungsi sebagai makanan yang pertama kali masuk ke saluran pencernaannya pada hari itu sehingga bagi sebagian anak, jajanan menjadi penting sebagai pemasok tenaga selama jam-jam pelajaran sekolah. Jajanan pinggir jalan di depan sekolah bagaikan dua sisi mata uang, sisi baik dan sisi buruk berjalan beriringan. Di satu sisi jajanan ini diperlukan sebagai asupan gizi bagi anak sekolah tetapi di sisi lain makanan ini mungkin mengandung berbagai zat tambahan yang berbahaya bagi tubuh manusia seperti pewarna buatan, penyedap dan pengawet makanan serta zat kontaminan lainnya (Anggiarini dkk. 2018).

Pernyataan sikap minuman yang berwarna dan beraroma tidak membawa akibat buruk dari kesehatan merupakan kalimat negatif. Sebelum kegiatan, 0,7 memilih sikap bahwa minuman yang berwarna dan beraroma membawa akibat buruk bagi kesehatan dan jumlah ini meningkat menjadi 0,9 setelah kegiatan. Seperti yang diketahui minuman yang beraroma dan berwarna dicurigai banyak yang mengandung pewarna tekstil dan tidak memenuhi syarat kesehatan. Makanan dan minuman yang sudah kadaluarsa tidak aman dikonsumsi.0,8 siswa memilih sikap untuk tidak mengkonsumsi makanan tersebut dan jumlah ini meningkat menjadi 1,0 setalah kegiatan. Ini tentu memberi harapan agar siswa lebih teliti dalam membeli makanan dan meneliti tanggal kadaluarsa produk. Sikap mencuci tangan sebelum makan dan minum diambil oleh 0,9 siswa sebelum kegiatan dan 1,0 siswa setelah kegiatan. Hal ini dimaksudkan untuk menghindari cemaran biologi yang berasal dari tangan siswa. Pada tahun 2016 penyebab keracunan KLB yang teridentifikasi, penyebab terbanyak adalah mikrobiologi (30\% diduga dan 3,33\% terkonfirmasi). Dari sisi etiologi 
penyebab yang terkonfirmasi adalah Bacillus cereus dan Staphylococcus aureus Sedangkan bakteri yang termasuk kategori diduga penyebab adalah Salmonella spp, Clostridium perfringens, Pseudomonas aeruginosa. $B$. cereus dan $S$. aureus merupakan bakteri yang diduga sebagai penyebab pada sebagian besar KLB. (Hariyadi dkk, 2018).

Sikap membawa bekal ke sekolah diambil oleh 0,8 siswa sebelum kegiatan dan menjadi 0,9 setelah kegiatan berakhir. Sikap pembatasan konsumsi fastfood diambil oleh 0,8 siswa sebelum kegiatan dan menjadi 1,0 siswa setelah kegiatan dilaksanakan. Terjadi perbaikan sikap sebanyak 0,9 dari 4,9 menjadi 5,75.

Tabel 6. Kategori Sikap Siswa terhadap Jajanan Aman Sebelum dan Sesudah Kegiatan

\begin{tabular}{lcc}
\hline Kategori Sikap & $\begin{array}{c}\text { Sebelum } \\
\text { kegiatan }\end{array}$ & $\begin{array}{l}\text { Setelah } \\
\text { kegiatan }\end{array}$ \\
\hline Kurang baik & 37 & 5 \\
\hline Baik & 63 & 95 \\
\hline Total & 100 & 100 \\
\hline
\end{tabular}

Berdasarkan nilai dari masing-masing siswa, maka didapatkan bahwa tingkat pengetahuan siswa sebelum kegiatan sebanyak 37\% yang kurang baik dan 63\% yang tergolong baik. Sedangkan setelah kegiatan, terdapat 5\% yang memiliki tingkat pengetahuan yang kurang baik dan 95\% yang baik. Hal ini menunjukkan kegiatan yang dilakukan memberi dampak yang baik bagi pergeseran tingkat pengetahuan dari kurang baik menjadi baik. Untuk mengetahui perbedaan tersebut, maka diuji dengan Wilcoxon. Hasil uji seperti tabel 6.

Tabel 7. Uji Wilcoxon Sikap terhadap Jajanan Aman

\begin{tabular}{|c|c|c|c|c|}
\hline Variabel & Rata-rata & Min & Max & Nilai $\mathrm{P}$ \\
\hline $\begin{array}{l}\text { Sikap } \\
\text { Sebelum } \\
\text { Intervensi }\end{array}$ & $4,90 \pm 1,432$ & 0 & 6 & 0,000 \\
\hline $\begin{array}{l}\text { Sikap } \\
\text { Sesudah } \\
\text { Intervensi }\end{array}$ & $5,75 \pm 0,557$ & 4 & 6 & \\
\hline
\end{tabular}

Dari uji didapatkan bahwa nilai $\mathrm{P}=0,000$, dimana $\mathrm{P}<0,05$ sehingga dapat disimpulkan bahwa perubahan sikap sebelum dan setelah perlakukan adalah signifikan.

\section{Pengujian Sampel Makanan}

Pengambilan sampel uji makanan dilakukan oleh petugas BPOM dibantu oleh mahasiswa Prodi D III Farmasi. Sampel makanan diuji dengan rapid test yang diuji oleh Petugas Balai Pengawas Obat dan Makanan di Gorontalo. Adapun hasil pengujian adalah sebagai berikut:

Tabel 8. Hasil pengujian jajanan anak sekolah di MIN 1 Kota Gorontalo

\begin{tabular}{llll}
\hline No & Kode Penjual & Jenis Sampel & Keterangan \\
\hline 1 & Ny.Y & Tahu Goreng & Aman \\
\hline 2 & Tn.A & $\begin{array}{l}\text { Pisang } \\
\text { Goreng }\end{array}$ & Aman \\
\hline 3 & Ny.Y & $\begin{array}{l}\text { Pisang } \\
\text { Goreng }\end{array}$ & Aman \\
\hline 4 & Ny.R & Es Lilin & Aman \\
\hline 5 & Ny.AS & Roti Goreng & Aman \\
\hline 6 & Ny.MS & Ayam Goreng & Aman \\
\hline 7 & Ny.ST & Bakwan & Aman \\
\hline 8 & Ny.HT & Kerupuk & Aman \\
\hline 9 & Ny.IY & Belekoa & Aman \\
\hline 10 & Tn.M & Bakso & Aman \\
\hline & & Pentolan & \\
\hline
\end{tabular}

Dari 10 sampel makanan yang diuji semua menunjukkan hasil yang negatif untuk uji metanil yellow, borax, formalin, dan rhodamin $B$. sehingga dapat disimpulkan makanan tersebut aman dari cemaran kimia berbahaya. Namun tidak dilakukan uji biologis terhadap sampel dimaksud.

\section{Kesimpulan}

Kegiatan penyuluhan Membangun Kesadaran Jajanan Aman pada Anak Sekolah di MIN 1 Kota Gorontalo berjalan dengan baik.

Pengetahuan siswa tentang jajanan aman adalah sebelum penyuluhan adalah 3,79 dan setelah sebesar 4,65.

Sikap siswa tentang jajanan aman adalah sebelum penyuluhan adalah 4,90 dan setelah sebesar 5,75. 
Tingkat pengetahuan siswa MIN 1 Kota Gorontalo 35\% kurang baik dan 65\% baik. Sedangkan setelah kegiatan menjadi $10 \%$ kurang baik dan $95 \%$ baik.

Sikap siswa MIN 1 Kota Gorontalo sebelum kegiatan adalah $37 \%$ kurang baik dan $63 \%$ baik, sedangkan setelah kegiatan $5 \%$ kurang baik dan $95 \%$ baik.

Hasil pengujian Wilcoxon menunjukkan bahwa penyuluhan tentang jajanan aman telah mampu mengubah pengetahuan secara signifikan dengan nilai $\mathrm{P}=0,000$, dimana $\mathrm{P}<0,05$.

Hasil pengujian Wilcoxon menunjukkan bahwa penyuluhan tentang jajanan aman telah mampu mengubah sikap secara signifikan dengan nilai $\mathrm{P}=0,000$. dimana $\mathrm{P}<0,05$.

Hasil pengujian jajanan didapatkan 10 sampel uji negatif mengandung metanil yellow, rhodamin B, borax, dan formalin.

\section{Daftar Pustaka}

Anggiarini, A dkk. 2018. Pelaksanaan Kebijakan Pemerintah Daerah Terkait Bahan Tambahan Pangan Pada Jajanan Anak Sekolah Menurut Permenkes No. 033 Tahun 2012 (Studi di Kabupaten Jepara). Jurnal Hukum Khaira Ummah: Semarang

Aprilianti, A, dkk. Studi Kasus Penggunaan Formalin Pada tahu Takwa di Kotamadya Kediri. Skripsi. Makassar: Astariwati, B. 2016. Pemilihan Makanan Sehat, Aman, Dan Bersih (Jajanan Sehat Untuk Anak Usia SD. Presentasi Makanan Sehat Anak Sekolah.

Badan Pengawas Obat dan Makanan (BPOM). 2009. Sistem Keamanan Pangan Terpadu Jajanan Anak Sekolah. http://bpom.go.id

Ditjen Bina Gizi, 2011. Pedoman Kemanan Pangan Sekolah Dasar. Kementerian Kesehatan Republik Indonesia. Jakarta

Kemenkes RI, 2014. Situasi Pangan Jajanan Anak Sekolah. Infodatin Pusat Data dan Informasi Kemenkes RI

Ningrum, W \& Wulan, N. 2017. Keamanan pangan anak sekolah dasar di kelurahan pekajangan kecamatan kedungwuni terhadap persepsi orang tua dan guru. The Fifth Urecol Proceeding. UAD. Yogyakarta.

Pakhri, A., Mashuria, A., Nuralim. 2014. Pengetahuan dan kebiasaan konsumsi makanan jajanan pada anak SDN Baddoka Makassar. Media Gizi Pangan, Vol. XVIII, Edisi 2, Makassar 